\title{
Distribution patterns and conservation status of Crocus species in Iran, one of the diversity centers of Crocus in the Middle East
}

\author{
Melika Tabasi, Ahmadreza Mehrabian*, Sadaf Sayadi \\ Department of Plant Sciences and Technology, Faculty of Life Sciences and Biotechnology, Shahid Beheshti \\ University, GC, Tehran, Iran
}

\begin{abstract}
Tabasi, M., Mehrabian, A., Sayadi, S., 2021. Distribution patterns and conservation status of Crocus species in Iran, one of the diversity centers of Crocus in the Middle East. Folia Oecologica, 48 (2): 156-168.

Assessing distribution patterns of valuable taxa plays an important role in the biodiversity conservation of these taxa. The genus Crocus L. (Iridaceae) comprises about 100 species that are distributed mainly in the Mediterranean region and western Asia. The present study purposed to assess the distribution patterns of Iranian Crocus species (including C. sativus L. and 8 wild species) and their conservation status in Iran as one of diversity centers of Crocus in the Middle East. A set of geographic distribution data was compiled through field studies, and reviews of herbarium specimens, iNaturalist, and various Flora. Localities were marked on geo-referenced maps (1/106) of Iran using ArcView version 3.2 (ESRI, 2000). The distribution patterns of the taxa were mapped per $0.25^{\circ} \times 0.25^{\circ}$ universal transverse Mercator grid cells $\left(25 \mathrm{~km}^{2}\right.$ with the exception of boundary area). Based on the species distribution (SDI) (33\%) and species specialization (SSI) (44\%) indices, those Iranian Crocus species that are threatened are mainly distributed in Irano-Turanian region. The mountainous ecosystems of Almeh and Western Alborz are important distribution centers of these taxa. Iranian Crocus species with SSI $<0.5$ (C. almehensis, C. gilanicus, C. michelsonii, and C. caspius) have the highest conservation value.
\end{abstract}

\section{Keywords}

conservation, crop wild relatives (CWR), distribution, Iridaceae, saffron

\section{Introduction}

The increasing rate of irreversible damage to ecosystems has reinforced the requirement for compiling basic biodiversity data for conservation management (MUTKE and BARTHLOTT, 2005). Habitats that may support focal species must be identified, and how to prioritize lands to protect sustainable populations of priority taxa must be assessed (Prendergast et al., 1999). Accordingly, pinpointing priority habitats is the main target of conservation biologists (Margules and Pressey, 2000). Some approaches focus on prioritizing zones by maximizing the number of threatened taxa (MYERs et al., 2000; DIETZ and CzECH, 2005). Others prioritize on the basis of surrogates (e.g., keystone, flagship, umbrella, etc.) (CARO, 2010). In yet other approaches, emphasis is placed on endemism, diversity, and hotspots (MYers, 1990; BARTHLOTT et al., 1996; MYers et al., 2000), or on economic and valuable taxa (crop wild relatives, medicinal, and ornamental) (Maxted et al., 2006; De Oliveira et al., 2007; SAyadi and Mehrabian, 2016; Mehrabian et al., 2020).

Several conservation studies have been conducted on a global scale, including research on the global patterns of plant biodiversity (SCHEINER and REY-BENAYAS, 1994;

\footnotetext{
*Corresponding author: e-mail: a_mehrabian@sbu.ac.ir 
KrAEFTE and Jetz, 2007), continental patterns of plant biodiversity (MUTKe and BARTHLOTT, 2005), diversity centers of rare and endangered taxa (Dobson et al., 1997; Prendergast et al., 1993), and diversity centers of crop wild relatives (IRIONDO et al., 2008). Furthermore, distribution patterns of endemic plants in Iran (HEDGE and Wendelbo, 1978), Iranian endemic monocotyledons (Mehrabian et al., 2015), and Iranian crop wild relatives (GP1) (MeHrabian and SAYADI, 2018) are other focuses of prominent studies on the regional scale.

In addition, some studies have evaluated geographic distribution patterns of Crocus species, the results of which can be used to determine conservation priorities and design conservation programs for the mentioned taxa. Assessment of the geographic distribution of Crocus series Reticulati (HARPKE et al., 2014) and assessment of the geographic distribution of C. biflorus Mill. as well as the distribution of their populations across phytogeographical regions in Anatolia (Kerndorf and PASCHe, 2006) are examples of such studies. Mehrabian et al. (2021) determined that two endemic Crocus species in Iran (C. almehensis Brickell $\&$ Mathew. and C. gilanigus B. Mathew.) are distributed only in restricted regions of Iran and should be considered a priority for conservation. The importance of the Crocus genus (especially C. sativus L. and its wild relatives), guides the design of strategies for the management and conservation of the genetic resources of this valuable genus (FERNÁNDEZ et al., 2011). Furthermore, some studies have evaluated the ecological variables in distribution regions of the Crocus species. In these studies, the effects of various factors, such as precipitation (JAFARBEYGLU and MobARAKy, 2008; TABASI et al., 2015) and temperature (BENSCHOP, 1993; BADRI et al., 2007; LundMARK et al., 2009) on the growth of these taxa have been evaluated. Soil features (i.e. $\mathrm{pH}$, texture, organic matter, etc.) in distribution regions of some Crocus species have also been studied (Satil and Selvi, 2007; ŞIK and Candan, 2009; KHatTaK and KhatTaK, 2011; Kandemir, 2009; KANDEMIR et al., 2012). Ecological factors can be used in the distribution modeling of Crocus species with the aim of recognizing priority species for conservation based on predicted distribution patterns. For this purpose, we are mapping the distribution patterns of Crocus species in Iran in another study. Distribution modeling of C. cyprius Boiss. \& Kotschy. in Cyprus (LoucA et al., 2015) is also an example of such studies.

Approximately 7,800 plant taxa comprise the flora of Iran (AssaDi et al., 1988-2018), 2,200 of which are confined to the geographical boundaries of Iran (MeHRABIAN et al., 2015; Mehrabian et al., 2020). The climatological diversity, history of vegetation, geographical isolation (Frey and Probst, 1986), complex tectonic history (Stöcklin, 1968), special soils (Hedge and Wendelbo, 1978), and intersection of diverse phytogeographical units (TAKHTAJAN, 1986; Zahran, 2010) lead to the high potential of this region for diversification and make it a global center of diversity for plants (DAVIS et al., 1994; BARThlotT et al., 1996; KIER et al., 2005) and one of the most important distribution centers of crop wild relatives in the world (VAVILOV, 1926).
The genus Crocus L. (Iridaceae) contains about 100 species distributed throughout the world (PETERSEN et al., 2008; Peruzzi and CARTA, 2011). The main area of Crocus species distribution is confined to the Mediterranean phytochorion that extends into the Irano-Turanian region (NEGHBI, 1999). Crocus species of Iran belonging to the subgenus Crocus (Mathew, 1982) are as follows: C. almehensis, $C$. gilanicus, C. biflorus, C. sativus, C. cancellatus Herb., C. caspius Ficher \& Meyer., C. michelsonii B. Fedtsch., $C$. speciosus M. Bieb., and C. pallasii Goldb. (which is also reported as C. haussknechtii Boiss. by RESHINGER, 1975). Saffron (C. sativus) is a very old domesticated species which dates back to $1600-1700 \mathrm{BC}$ and is also found in Crete (Algrech, 2001). YuE et al. (2020) showed that the current genome of $C$. sativus is probably a product resulting from at least two rounds of whole-genome duplication (WGD) events that occurred $\sim 28$ and $\sim 114$ million years ago, respectively. However, the Middle East, central Asia, and the islands of SW Greece have been determined as the origins of saffron (TAMmaro, 1987; VAVILOv, 1951). Due to the high industrial, ornamental, and medicinal value of saffron, improving the quality of this product by relying on natural methods (e.g., cross with wild relatives) is very important. It has been suggested that wild relatives of $C$. sativus can be used to improve its quality (NEGHBI, 1999).

Determining the distribution patterns of these valuable taxa has an important role in identifying various ecotypes so as to promote the genome of cultivated saffron. Moreover, determining distribution areas, conservation status, and conservation priority of its wild relative species is one effective way to protect these unique genetic resources. To date, little attention has been paid to the distribution patterns and priorities for conservation of these valuable taxa. Thus, the ecological assessment of these species seems to be necessary. The aims of the present study included: 1. Assessment of distribution patterns of Crocus species in Iran as one of diversity centers of Crocus in the Middle East; 2. Assessment of their conservation status to determine priority taxa and areas for designing conservation programs. Furthermore, the distribution and diversity of the mentioned taxa was analyzed using a geobotanical and phytogeographical approach.

\section{Materials and methods}

\section{Study area}

Iran, the dominant segment of the Iranian Plateau, covers an area of 1.6 million $\mathrm{km}^{2}$ and is located between $35^{\circ} 41^{\prime} \mathrm{N}$ latitude and $51^{\circ} 26^{\prime} \mathrm{E}$ longitude. The diversity of geological structures shapes a broad range of physical conditions that form several phylogeographical zones for speciation and endemism.

Iran includes several wide spectra of prominent geomorphologic formations, including Zagros, Alborz, Kopet Dagh, Makran, and several scattered internal mountain ranges. The Zagros is a natural massif that spreads between the plateaus of Iran and Mesopotamia and the Persian Gulf with a northwest-southeast orientation 
from eastern Turkey to southwestern Iran, a mean elevation of $1,200 \mathrm{~m}$ above sea level (asl), and the highest peak at 4,231 $\mathrm{m}$ asl (Zard Kuh) (HomKe et al., 2004). Alborz, as an important segment of the Alpine-Himalayan system, forms a gently sinuous shape that stretches across the southern parts of the Caspian Sea (STöCKLIN, 1974). The southern slopes are confined by the central plateau (STÖCKLIN, 1974). Kopet Dagh extends from the eastern borders of the Caspian Sea to northeastern Iran, Turkmenistan, and northern Afghanistan (LyBERIS and MANBY, 1999). These natural walls surround the central parts of Iran and prevent the infiltration of moisture into the country. Thus, Iran has various rainfall patterns. Iran is situated in the global arid zones that obtain very little precipitation (equivalent to $1 / 3$ of the average global precipitation) (SHAKUR et al., 2010). In addition, Iran is comprised of seven geological zones: the Khuzestan plain, folded zone, Iranians, central plateau, Alborz Mountains, Turkman-Khurasan Mountains, and Caspian littoral, and bioclimatic zones (Fig. 1) (DEWAN and FAMOURI, 1964).

\section{Methodology}

A geographic distribution database of Crocus species was established using records corresponding to 510 stations of Crocus. These records were provided by a review of Flora of Iran (AssADI et al., 1999), Flora Iranica (RESHINGER, 1975), the illustrated flora of Golestan National Park (AKhani, 2005), Flora of USSR (FedChenko, 1935), Flora of Egypt (Tä̈KHOLM and DraR, 1973), Flora of Turkey and the East Aegean Islands (MATHEw, 1984), Flora of Iraq (Wendelbo, 1985), Flora of Palestine (Dothan, 1986), Flora of Syria, Palestine, and Sinai (Post, 1933), and Flora of Syria (online). Geographic distribution information of plant specimens was obtained from the review of several herbaria, i.e. Herbarium of Shadid Beheshti University (HSBU), Tehran University Herbarium (TUH), Ferdowsi University of Mashhad Herbarium (FUMH), personal Herbarium of Dr. Akhani, Herbarium of Hakim Sabzevari University, Herbarium of Payame Noor University of Sari, and Virtual Herbaria of Wien: http://herbarium. univie.ac.at/database/search.php and iNaturalist (https:// inaturalistorg) and collected in field studies conducted between 2012-2018.

Ecological factors (e.g., latitude, longitude, and altitude) for some plant samples without geographic coordinates were provided by Google Earth ver. 5.1. The collected data was analyzed using multivariate techniques, i.e. principal component analysis (PCA) by PAST software (HAMmer et al., 2001).

ArcGIS (ESRI, 2000) was used to analyze the distribution patterns and assess conservation priorities. Mapping analyses were conducted per $0.25^{\circ} \times 0.25^{\circ}$ universal transverse Mercator grid cells $\left(25 \mathrm{~km}^{2}\right.$ with the exception of boundary area).

Formations of Iranian plant communities were classified based on Frey and Probst (1986) and Zohary (1973). Assessment of conservation status was based on the IUCN Red List at the regional scale (IUCN, 2011). The conservation value included the index of species rarity in the study area (RI) based on WILLIAMS et al. (1996) and the index of species distribution (SDI) based on TsifTsIs et al. (2009) and was calculated as: $\mathrm{RI}=1 / C i$, where $C i$ is the number of grid cells and 1 is the number of present taxa. The SDI was calculated as SDI $=1-C i$ / $C$, where $C$ is the total number of grid cells. The species specialization index (SSI) based on geological, geomorphological, and climatic features was calculated based on DoLÉDEC et al. (2000). The SSI $=1-T i / T_{\max }$, where $T i$ is the tolerance $(\%)$ of $i$ th species, and $T_{\max }$ is the maximum value of species tolerance $(\%)$ recorded. Species with SSI $<0.5$ have the highest conservation value.

\section{Results}

In the flora of Iran, the genus Crocus L. is represented by 9 species belonging to the sections Crocus (i.e. C. gilanicus, C. haussknechtii, and the cultivated species C. sativus) and Nudiscapus Mathew (i.e. C. almehensis, C. cancellatus, C. biflorus, C. caspius, C. michelsonii, C. speciosus) (MATHEW, 1982).

According to the current results, these taxa are distributed in diverse geomorphologic units of Iran as follows: $C$. almehensis in the restricted zones of Almeh (northwest); C. biflorus in the eastern zones of Alborz, western zones of Kopet Dagh, and northern Zagros; C. cancellatus in northern and central Zagros; C. caspius in central Alborz; C. gilanicus in western Alborz; $C$. haussknechtii in central Zagros; C. michelsonii in Kopet Dagh; and C. speciosus in the western zones of central Alborz and eastern Alborz. Moreover, C. sativus is cultivated widely in various areas of Iran (Fig. 2). Crop wild relatives in other zones of the Middle East are distributed especially in the Caucasus and Nakhichevan regions (C. speciosus), south-western zones of Syria and east of Lebanon (C. haussknechtii), the Kopet Dagh mountain of Turkmenistan (C. michelsonii), the Zagros mountains of Iraq, and the Taurus mountains of Turkey (C. cancellatus), and the south and center of Turkey (C. biflorus) (Fig. 3a).

The highest richness of Iranian Crocus species is centered in $36^{\circ}-38^{\circ}$ geographical latitudes in the Alborz Mountains. Species occurrence varied from 1 to 4 per grid cell (Fig. 3b).

These taxa are distributed in 200 of 624 grid cells as follows: C. almehensis (3), C. gilanicus (6), C. biflorus (13), C. michelsonii (9), C. cancellatus (27), C. caspius (27), C. haussknechtii (35), C. speciosus (28), and C. sativus (112). However, species distribution on the basis of geographical latitude is as follows: C. almehensis $37^{\circ}-38^{\circ}$, C. biflorus $34^{\circ}-40^{\circ}$, C. cancellatus $29^{\circ}-38^{\circ}$, C. caspius $36^{\circ}-38^{\circ}, C$. gilanicus $36^{\circ}-38^{\circ}$, C. haussknechtii $28^{\circ}-37^{\circ}$, C. michelsonii $37^{\circ}-38^{\circ}$, C. speciosus $33^{\circ}-39^{\circ}$, and C. sativus $28^{\circ}-39^{\circ}$. These taxa are mainly distributed in Alborz (North and North west), Kopet Dagh (North east), and Zagros (West), respectively (Fig. 2j).

The elevation patterns of the taxa can be classified as alpine $(>2,500 \mathrm{~m})$, sub-alpine $(1,200-2,500 \mathrm{~m})$, and mountain slopes-to-lowlands $(<1,200 \mathrm{~m})$ (KAPOs et al., 2000). However, many taxa show transitional habitats 

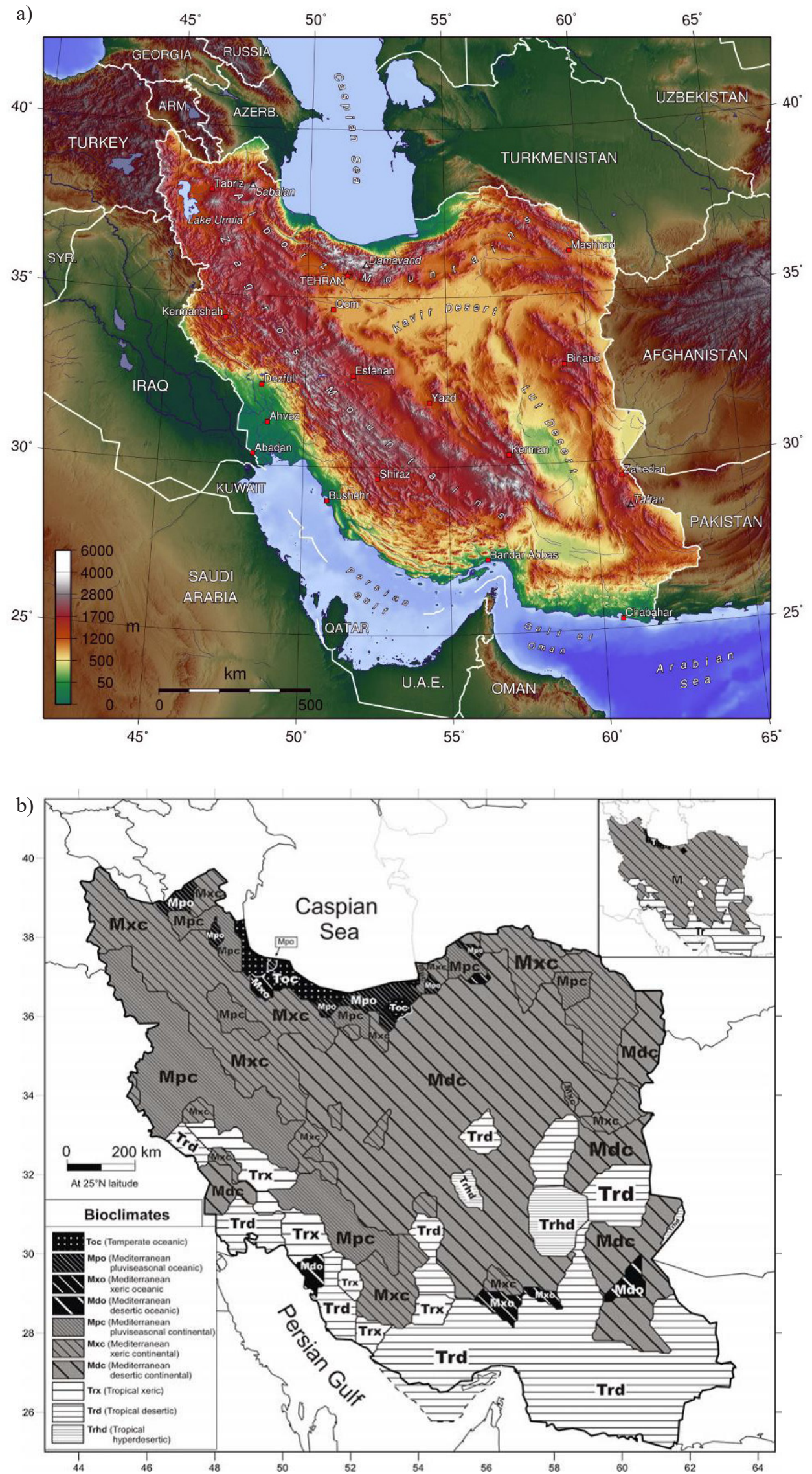

Fig. 1a. Geomorphological map of Iran (www.ngdir.ir), b. Bioclimatic zonation of Iran (DJAmaLI et al., 2011). 
a)

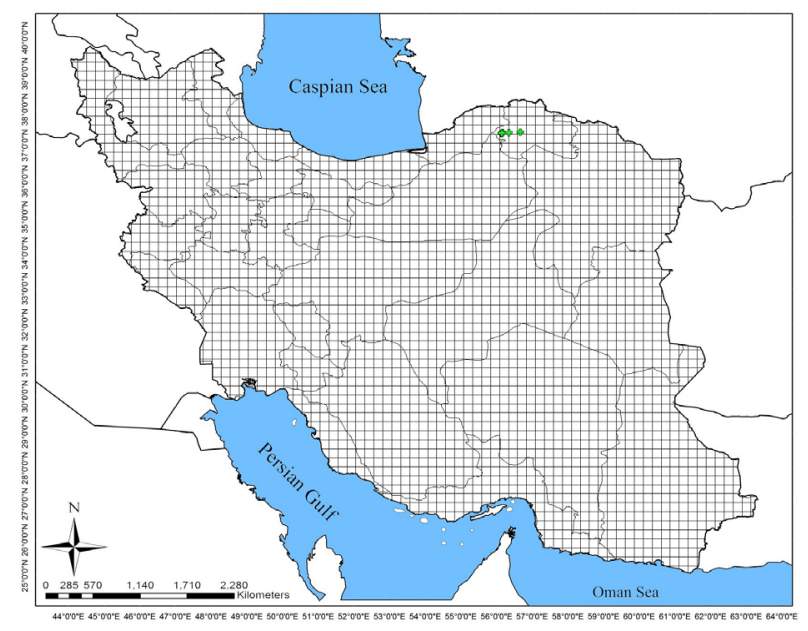

c)

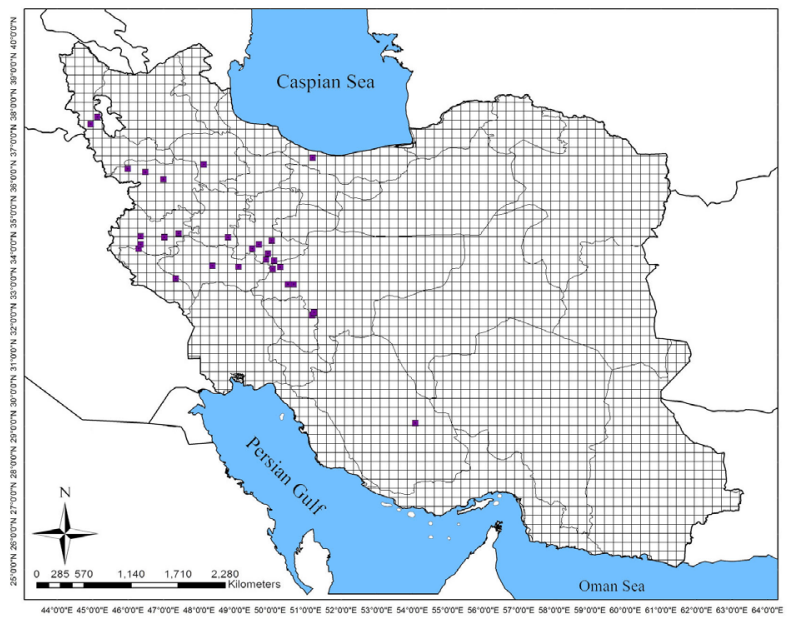

e)

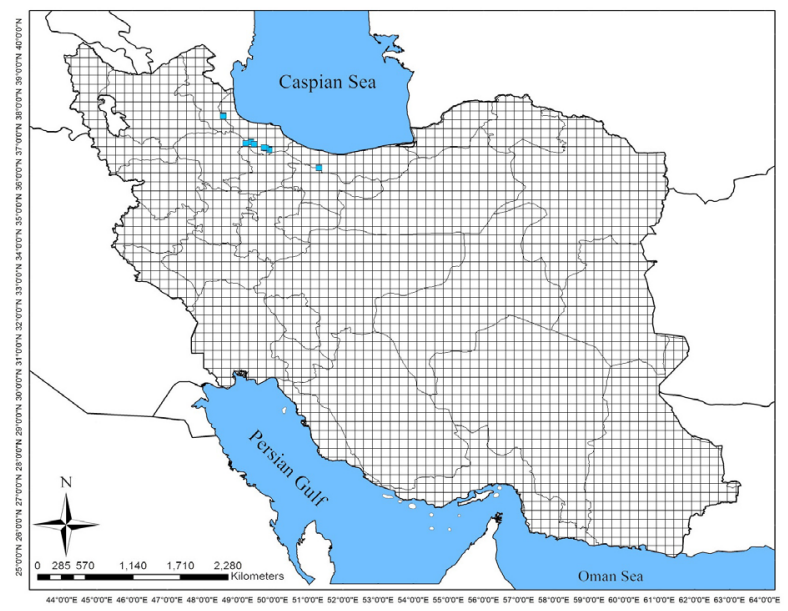

b)

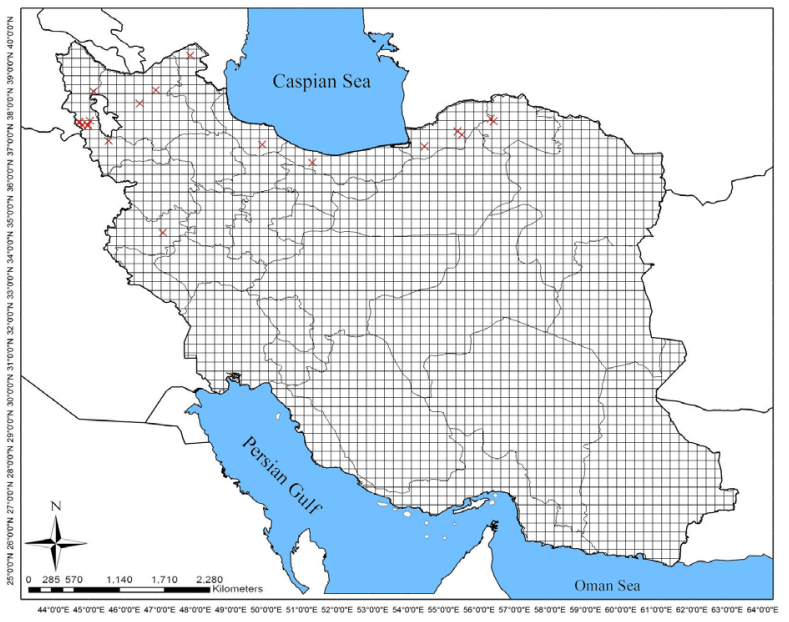

d)

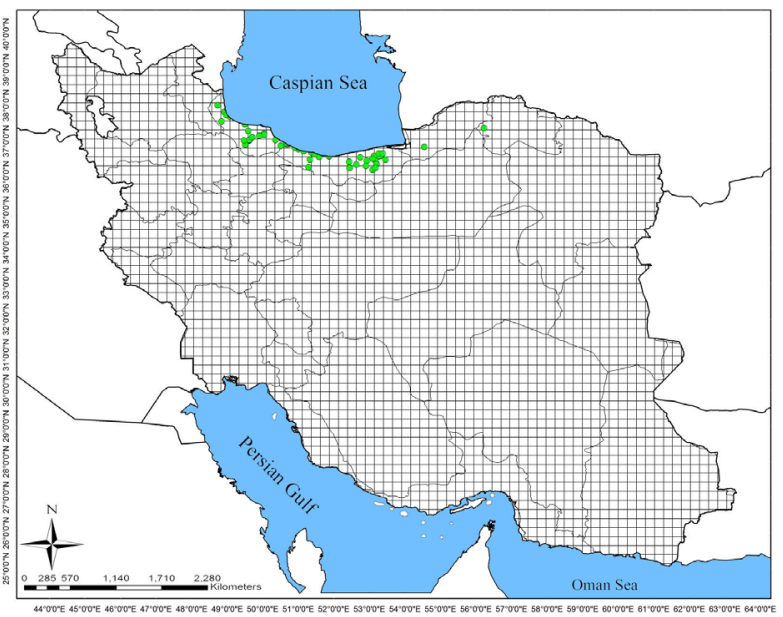

f)

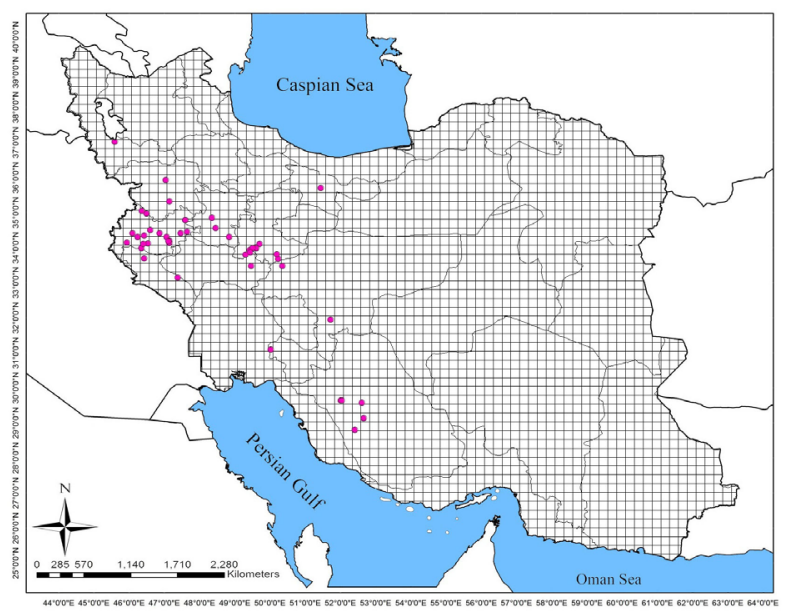

Fig. 2. Distribution patterns of Crocus taxa in Iran: a) C. almehensis (๘), b) C. biflorus (×), c) C. cancellatus (匹), d) C. caspius

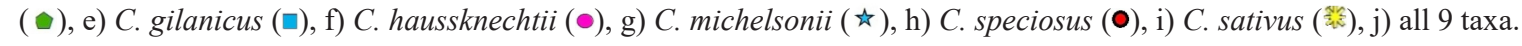


g)

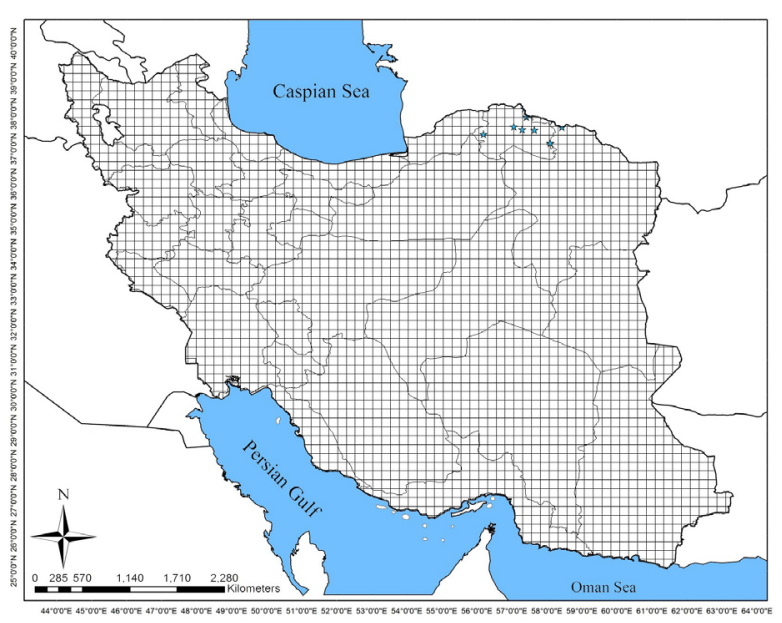

h)

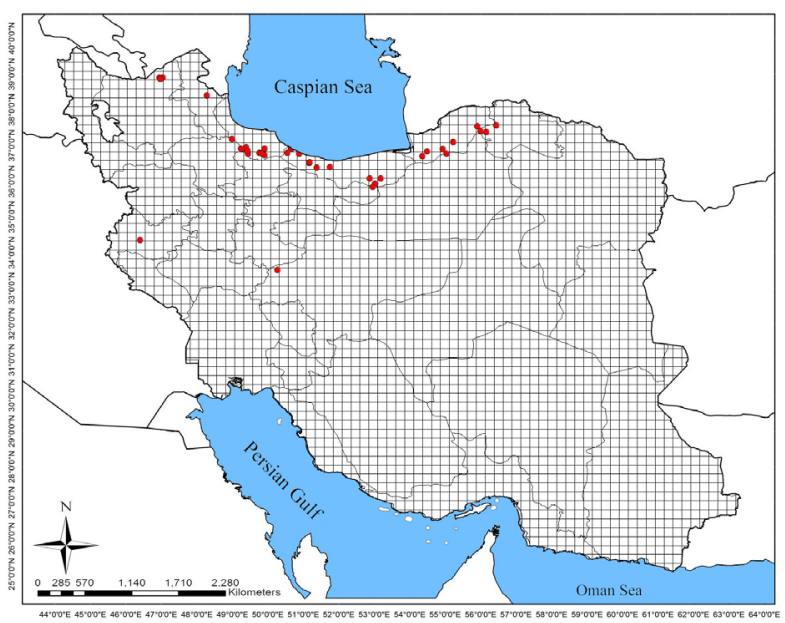

i)

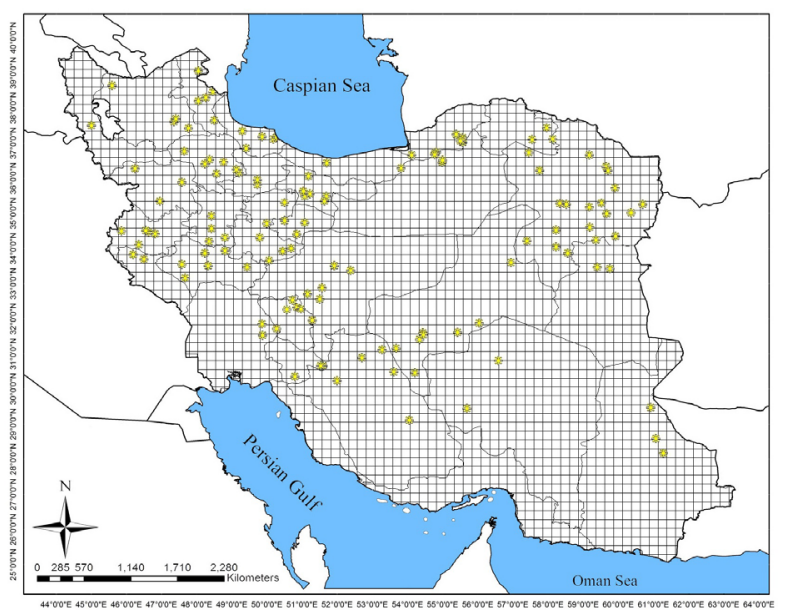

j)

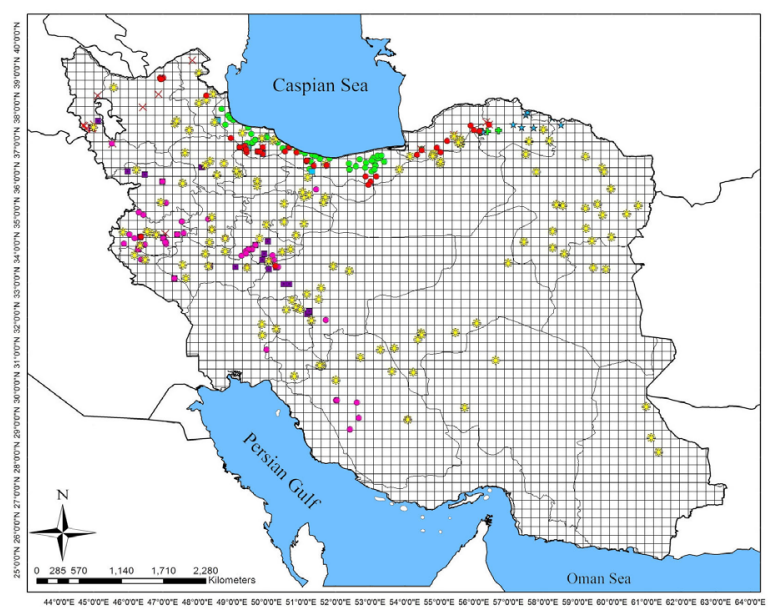

Fig. 2. Continued. Distribution patterns of Crocus taxa in Iran: a) C. almehensis (§), b) C. biflorus (×), c) C. cancellatus (匹), d) C. caspius ( $\bullet)$, e) C. gilanicus $(\square)$, f) C. haussknechtii $(\bullet)$, g) C. michelsonii (

and occupy all three zones. The altitudinal distribution of species in Iran is as follows: C. almehensis 1,600 to $2,165 \mathrm{~m}$, C. biflorus 130 to 2,258m, C. cancellatus 667 to $2,900 \mathrm{~m}, C$. caspius -23 to $1,873 \mathrm{~m}, C$. gilanicus 200 to $2,500 \mathrm{~m}, C$. haussknechtii 667 to $3,127 \mathrm{~m}$, C. michelsonii 1,035 to $2,300 \mathrm{~m}, C$. speciosus 250 to $2,500 \mathrm{~m}$, and $C$. sativus -21 to $2,231 \mathrm{~m}$; in the Middle East, it is as follows: C. biflorus 129 to $3,196 \mathrm{~m}$, C. cancellatus 215 to $2,900 \mathrm{~m}$, C. caspius -23 to $1,873 \mathrm{~m}$, C. haussknechtii 215 to $3,127 \mathrm{~m}$, C. michelsonii 1,035 to $2,300 \mathrm{~m}, C$. speciosus 247 to $2,500 \mathrm{~m}$, and $C$. sativus -21 to $3,428 \mathrm{~m}$. Two species, $C$. gilanicus and $C$. almehensis, are endemic taxa in Iran that occurr at $36^{\circ}-38^{\circ} \mathrm{N}$ latitude and 200 to $2,500 \mathrm{~m}$ elevation. PCA analysis was used to determine the influence of ecological factors (longitude, latitude, and altitude) on species distribution. The analysis results revealed that altitude is an important factor in the distribution pattern of wild Crocus species (especially C. almehensis) in Iran (Fig. 4).

Geology is highly effective for the delimitation of ecosystems and analysis of distribution patterns (PARENTI and EBACH, 2009). These taxa are distributed in sedimentary, igneous, and metamorphic rocks and quaternary deposits (simplified geological map of Iran www.ngdir.ir). In addition, they are distributed in diverse geomorphological units of Iran, including the northern, northwestern, northeastern, and eastern regions of Iran. However, C. almehensis and C. gilanicus as endemic taxa are distributed mainly in sedimentary rocks. C. biflorus is found in quaternary deposits and sedimentary rocks, C. cancellatus and C. haussknechtii in sedimentary and metamorphic rocks, C. caspius and C. michelsonii in sedimentary rocks, and $C$. speciosus in sedimentary and igneous rocks.

Rare taxa show a greater extinction risk than common taxa in similar ecological conditions (JoHnson, 1998; Matthies et al., 2004) because of their high sensitivity to demographic and environmental events (BoycE, 1992). Rare species (C. almehensis, C. gilanicus, and $C$. 

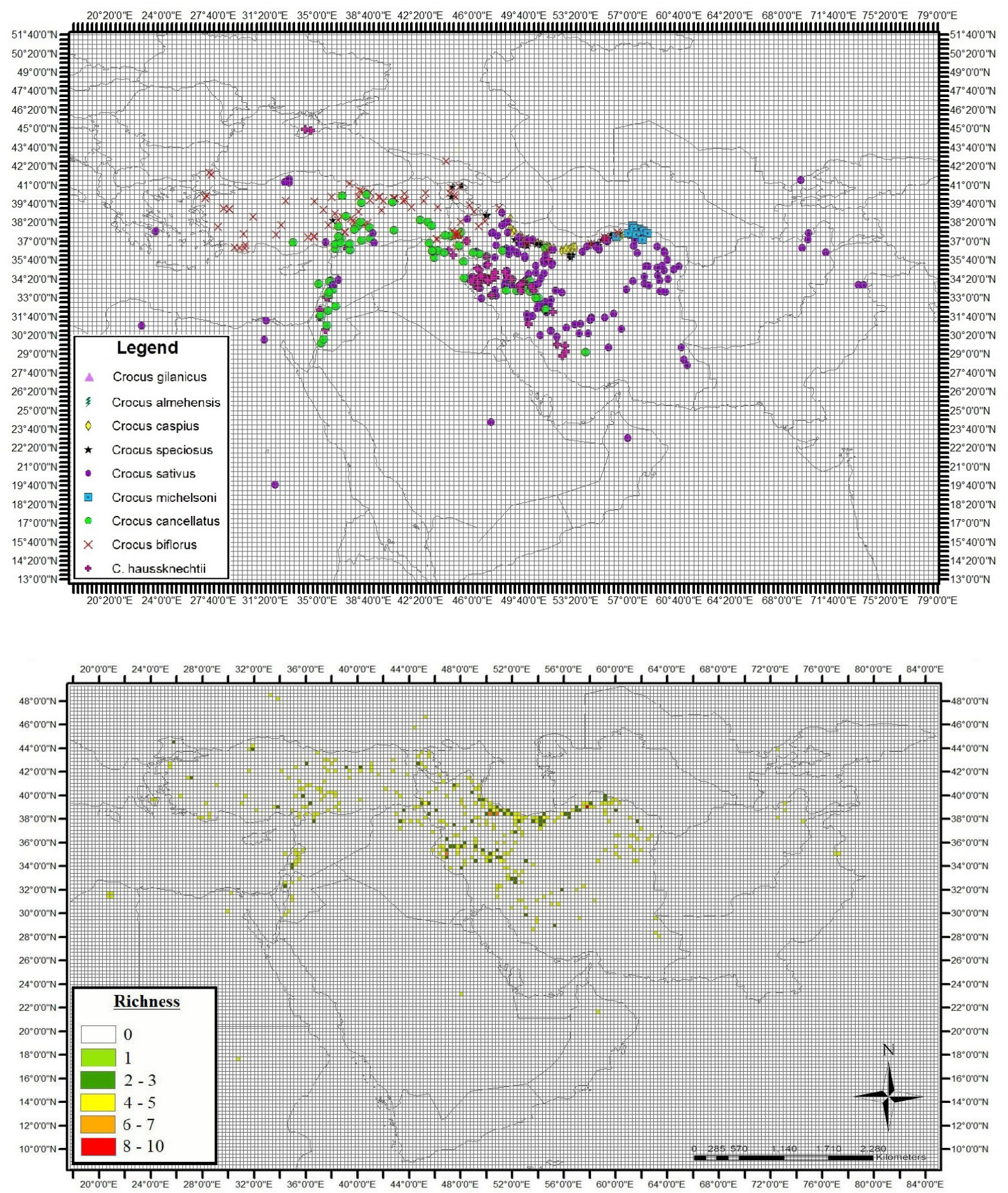

Fig. 3a. Distribution pattern and b. The richness map of Iranian Crocus species in the Middle East.

michelsoni) cover about $33.33 \%$ of the Iranian Crocus species (Table 1). All of these species are distributed in similar geological units (sedimentary rocks) and occurr between 200 and $2,500 \mathrm{~m}$.

The Crocus genus in the Middle East is found mostly in the Irano-Turanian region (Holarctic kingdom) in the western zone, Saharo-Arabian region (Holarctic Kingdom) in the northern zone, and the Mediterranean region in the eastern zone.
Determining diversity centers of Iranian Crocus is one of the basic essentials in determining the highest conservation priorities. The values of the Index species distribution are C. almehensis (0.004), C. gilanicus (0.009), and $C$. michelsonii (0.01), respectively. $C$. almehensis and C. gilanicus are two endemic species that are found mostly in similar geological units (sedimentary rocks) of Almeh Mountains and western Alborz, respectively. Based on geological, geomorphological, and bioclimatic features 

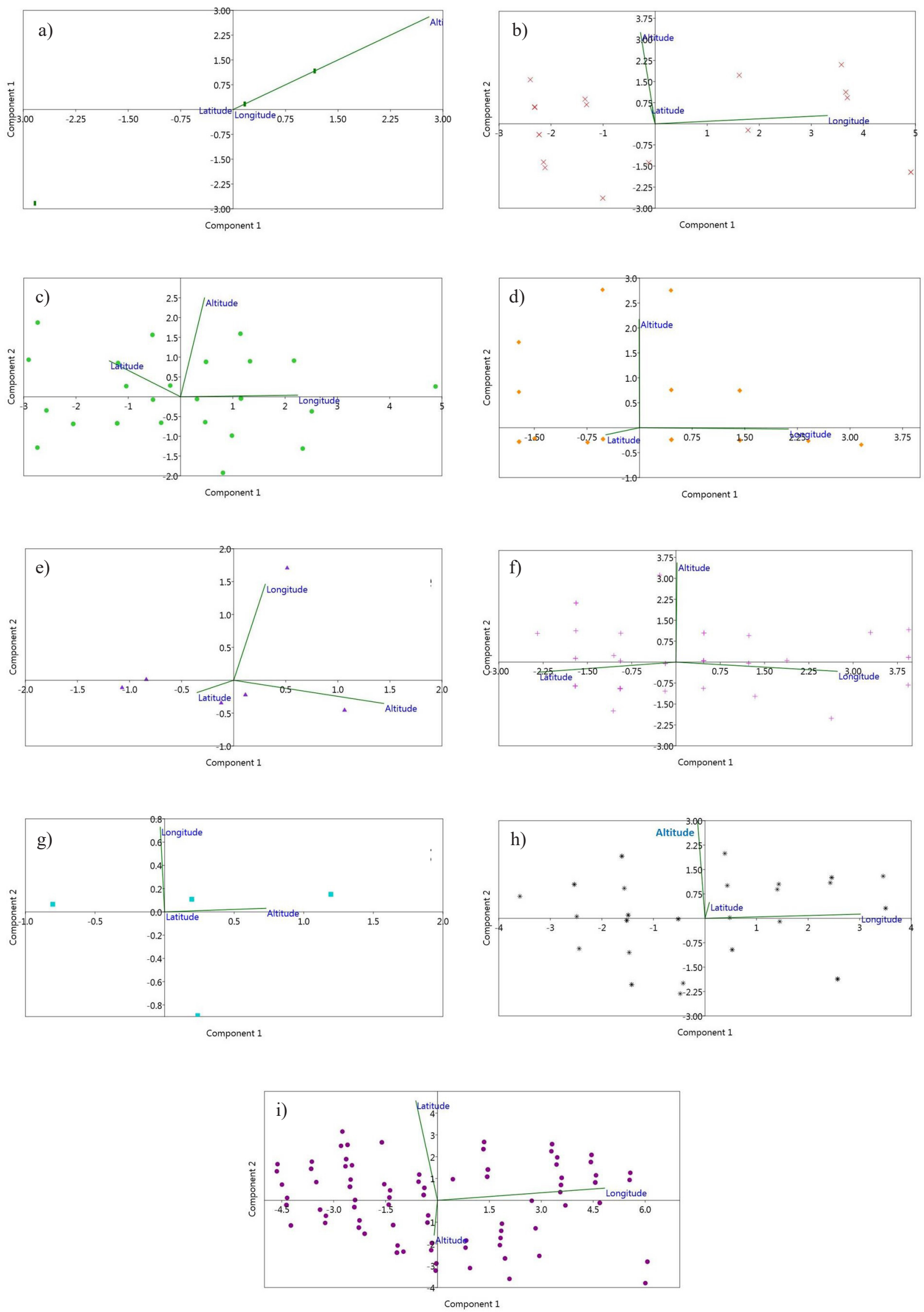

Fig. 4. PCA-ordination biplot of the Crocus species related to the ecological factors (longitude, latitude, and altitude) in Iran: a) C. almehensis, b) C. biflorus, c) C. cancellatus, d) C. caspius, e) C. gilanicus, f) C. haussknechtii, g) C. michelsonii, h) C. speciosus, i) C. sativus. 
(Fig. 1), C. almehensis, C. gilanicus, and C. michelsonii with the same SSI (0.38) and C. caspius (SSI $=0.48)$ have the highest priority for conservation, respectively (Table 1).

Table 1. Rarity and habitat-specificity of studied taxa in Iran. SDI, Index of species distribution; SSI, Species specialization index

\begin{tabular}{ccc}
\hline Species & SDI & SSI \\
\hline C. almehensis & 0.004 & 0.38 \\
C. biflorus & 0.02 & 1.13 \\
C. cancellatus & 0.04 & 0.78 \\
C. caspius & 0.04 & 0.48 \\
C. gilanicus & 0.009 & 0.38 \\
C. haussknechtii & 0.05 & 0.78 \\
C. michelsonii & 0.01 & 0.38 \\
C. speciosus & 0.04 & 1 \\
C. sativus & 0.17 & 1.65 \\
\hline
\end{tabular}

\section{Discussion}

This study is the first to investigate the distribution patterns of Crocus species in Iran based on the geographic information system (GIS). According to PETERSEN et al. (2008) and Peruzzi and CARTA (2011), the genus Crocus L. consists of about 100 recognized species throughout the world. These taxa occur from Western Europe and northwestern Africa to western China with the center of species diversity being in Asia Minor and on the Balkan Peninsula (HARPKE et al., 2003). The Crocus genus in Iran comprises 9 species that are distributed especially in the mountainous habitats of Alborz (North and North west), Kopet Dagh (North east) and Zagros (West). The most important distribution centers of the Iranian Crocus species in the Middle East are central and southern Turkey, NE Iraq, NE Armenia, SE Azerbaijan, E Lebanon, SW and NW Syria, and the Caucasus and Nakhichevan regions. The Crocus is known mainly for the precious aromatic and medicinal cultivated species, C. sativus (saffron), which is of prime economic importance. There are different opinions about the origin of saffron. This species probably originated in Iran and Greece, from where it later spread to India, China, the Mediterranean Basin, and Eastern Europe (Tammaro, 1987; Negbi, 1999). Vavilov (1951) proposed the Middle East (Asia Minor, Turkestan, and Iran) as the center of the origin of saffron. The ancestor of $C$. sativus is still in question. For example, based on morphological, cytological, and molecular analyses, LARSEN (2011) considered C. cartwrightianus Herb. as the most probable ancestor of $C$. sativus. ZuBor et al. (2004) found that $C$. sativus shares a high number of morphological similarities with $C$. cartwrightianus and C. thomasii Ten. According to Grilli Caiola et al. (2004), C. cartwrightianus, C. hadriaticus Herb., C. asumaniae B. Mathew \& T. Baytop., and $C$. pallasii Goldb. share the most similar fragments with C. sativus. However, based on the molecular study of Iranian Crocus species (SHEIDAI et al., 2018), C. pallasii is closely related to $C$. sativus.

The combination of a wide geographical range and the presence of dispersed populations make it possible for a plant species to harbor a vast amount of genetic variability; this genetic richness can be present in the form of either allelic variability or allelic uniqueness of some populations (PETIT et al., 1998). On the other hand, extensive selection and uniform breeding practices can bring about genetic erosion and lower the genetic variability of crop plants (PoczAI, 2011). Wild relatives of important crop plants may contain useful genes that can be introduced to a crop plant that has been under selection pressure for a long time. Due to the high cross-ability potential among Crocus species, there are possibilities of transferring useful genes in these taxa. In a molecular study of Iranian Crocus species (SHEIDAI et al., 2018), the studied populations were highly variable in respect to flower coloration due to intensive gene-exchange between genotypes. Therefore, it is suggested that the considerable genetic resources found in different Crocus species could be used to genetically improve $C$. sativus. Based on this data, it seems necessary to study the conservation status of wild Crocus species.

The Irano-Turanian and Mediterranean regions (TAKHTAJAN, 1986; ZOHARY, 1973) show higher diversity and endemism than adjacent areas (SAYADI and MeHrabian, 2016). These centers encompass the richness of endemic monocotyledons in Iran (Mehrabian et al., 2015). $C$. almehensis and $C$. gilanicus are two endemic Crocus species in Iran that occur at altitudes of 200 to $2,500 \mathrm{~m}$ and create a sensitive conservative zone along this elevation gradient. It is predicted that altitude affects the distribution patterns of wild plants with extremely small populations (CHEN et al., 2014). Furthermore, it is suggested that altitude is the most important determining factor of endemic species distribution patterns (BACARO et al., 2015). The results of the present study revealed that altitude is an important factor in the heterogeneity of distribution patterns of wild Crocus species in Iran.

Geology is highly effective in the delimitation of ecosystems and analysis of distribution patterns (PARENTI and ЕвасH, 2009). The endemic zones of the Crocus genus in Iran are situated mainly in sedimentary rock. Furthermore, two species, C. michelsonii and C. caspius, that are distributed more in Iran than in adjacent areas, are situated in the same geology. Geological evidence confirms the obtained results by Rechinger regarding soil's role in the creation of high endemism in Iran (Hedge and Wendelbo, 1978). Iranian Crocus species in the Middle East show a slight decrease from the Iranian plateau (SCHÖNBECK-TEMESY, 1972) to the Anatolian plateau (Sayadi and Mehrabian, 2016) and extend to the Golan Heights (Fig. 3).

According to the current results, three taxa $(33.3 \%)$ of Iranian Crocus species (C. almehensis, C. gilanicus, and $C$. michelsonii), with 3 to 9 populations, are the most threatened (critically endangered and endangered) taxa of Iranian Crocus species in the Middle East. A high 
percentage of threatened species are situated in the western Alborz Mountains in Iran and in Kopet Dagh. There are several threatening factors (e.g., land-use change, deforestation, and overgrazing) (AKHANI et al., 2010; JAFARI, 2010; MEHRABIAN, 2014) that put serious pressure on the habitats of these species. Providing a conservation plan for the protection of endangered species is necessary. Ex-situ methods can be used for the conservation of Crocus species (FERnándeZ et al., 2011).

The present study established the most important centers of diversity of the Iranian Crocus species in the Middle East. Based on these results, the Iranian Crocus species are widely distributed at altitudes up to $2,900 \mathrm{~m}$. The highest richness of species among the geographical latitudes in the Middle East is at $36^{\circ}-38^{\circ}$. Environmental factors play an important role in the distribution patterns of Iranian Crocus species (TABAsI et al., 2015). In this study, two ecological factors (altitude and longitude) were found to be the most important factors in the distribution patterns of these species.

Wild relatives of Crocus sativus are useful to saffron improvement as sources of a variety of valuable traits (Khoury et al., 2010). Among the wild Iranian Crocus species, C. pallasii is closely related to C. sativus (SHEIDAI et al., 2018). This species should be clearly mapped for the selection of important zones as possible plant microreserves (Heywood and Dullo, 2005) and genetic reserves in Iran and the Middle East.

Assessing the conservation status of the plant taxa is a preliminary step in managing plants and selecting priorities for conservation. The threated Iranian Crocus species in the Middle East, based on SDI (33\%) and SSI (44\%), are distributed mainly in Irano-Turanian phytochorion and below an altitude of $2,500 \mathrm{~m}$, which is a sensitive zone and must be included in conservation plans. C. almehensis and C. gilanicus (two Iranian endemic species) are considered to be threatened species on the regional scale of Iran. $C$. michelsonii with a restricted distribution in northeastern Iran and southern Turkmenistan (in Kopet Dagh zone) and C. caspius in the north of Iran, southeastern Azerbaijan, and Caucasus are critically endangered on the global scale.

Myers (1988, 1990) has classified hotspots for regions with specific concentrations of species richness, restricted endemics, and threatening factors. The factors considered for selection as priorities for conservation are as follows: species richness, rarity, endemism, and habitat-specificity. When resources for conservation are limited, the identification of priorities plays a key role in conservation (MYERs et al., 2000; BRUMMITT and LughadHA, 2003). According to the current results, highdensity biodiversity centers of the Iranian Crocus species are located in the northeastern and eastern Middle East. The highest richness of Iranian Crocus species occurred in the Alborz Mountains. Based on endemism, the mountainous ecosystem of Almeh and Western Alborz (located in Iran), as important distribution centers of Iranian Crocus species in Irano-Turanian region, should be included in conservation priorities. Based on habitat-specificity, the SSI for Iranian Crocus species ranges from 0.38 (Kopet Dagh and Western Alborz) to 1.65. Iranian Crocus species with SSI $<0.5$ have the highest conservation value (Table 1 ).

Climate change and several threatening factors (excessive harvesting, habitat destruction, livestock grazing, etc.) (JAFARI, 2010) in Iran put considerable pressure on the habitat of threatened Crocus species. It is necessary to design a conservation plan in order to protect these species. Ex-situ methods can be used for the conservation of Crocus species (FERNÁNDEZ et al., 2011) as complementary to in situ protection. These achievements provide valuable data which can be used to manage the endemic, rare, crop wild relatives of Crocus and prioritize habitats and geographical zones to design conservation plans for Iranian Crocus species in the Middle East.

\section{Acknowledgements}

We would like to thank the staff of Library and Documentation Center for Natural Resources of Iran (Research Institute of Forests and Rangelands, Karaj, Iran), as well as, Agricultural Scientific Information and Documentation Center (ASIDC) (Agricultural Research, Education and Extension Organization, Tehran, Iran) for their assistance in exploring the plant resources used in the present study.

\section{References}

Akhani, H., 2005. The illustrated flora of Golestan National Park, Iran. Vol. 1. Tehran: University of Tehran Press. $129 \mathrm{p}$.

Akhani, H., Duamali, M., Ghorbanalizadeh, A., Ramezani, E., 2010. Plant biodiversity of Hyrcanian relict forests, $\mathrm{N}$ Iran: an overview of the flora, vegetation, palaeoecology and conservation. Pakistan Journal of Botany, 42: $231-258$.

Algrech, C., 2001. The saffron of Quercy. Revue Quercy Recherche, 97: 20-27.

Assadi, M., Khatamsaz, M., Masoumi, A., Mozafarian, V., Babakhanlu, P., Zehzad, B. (eds), 1999. Flora of Iran. Vol. 31 (Iridaceae). Tehran: Research Institute of Forests and Rangelands Publication, p. 4-18. (In Persian).

Assadi, M., Maassoumi, A.A., Khatamsaz, M., Mozaffarian, V. (eds), 1988-2018. Flora of Iran. Vols. 1-147. Tehran: Research Institute of Forests and Rangelands Publications. (In Persian).

Bacaro, G., Maccherini, S., Chiarucci, A., Jentsch, D., et al., 2015. Distributional patterns of endemic, native and alien species along a roadside elevation gradient in Tenerife, Canary Islands. Community Ecology, 16: 223 234. https://doi.org/10.1556/168.2015.16.2.10

Badri, M.A., Minchin, P.E.H., Lapointe, L., 2007. Effects of temperature on the growth of spring ephemerals: Crocus vernus (L.) Hill. Physiologia Plantarum, 130: 67-76. https://doi.org/10.1111/j.1399-3054.2007.00882.x

Barthlott, W., Lauer, W., Placke, A., 1996. Global distribution of species diversity in vascular plants: towards a world map of phytodiversity. Erdkunde, 50 (41): 317-327.

Benschop, M., 1993. Crocus. In De Hertogh, A., Le Nard, 
M. (eds). The physiology of flower bulbs. Amsterdam: Elsevier Science Publishers, p. 257-272.

Boyce, M.S., 1992. Population viability analysis. Annual Review of Ecology and Systematics, 23: 481-506.

BRummitt, N., LughadHA, E.N., 2003. Biodiversity: where is hot and where is not hot. Conservation Biology, 17: 1442 1448. https://doi.org/10.1046/j.1523-1739.2003.02344.x

CARO, T., 2010. Conservation by proxy: indicator, umbrella, keystone, flagship, and other surrogate species. Washington: Island Press, p. 99-260.

Chen, Y., Yang, X., Yang, Q., Li, D., Long, W., Luo, W., 2014. Factors affecting the distribution pattern of wild plants with extremely small populations in Hainan Island, China. PloS One, 9: e97751. https://doi.org/10.1371/ journal.pone.0097751

Davis, S.D., Heywood, V.H., Hamilton, A.C., 1994. Centers of plant diversity. Natural History, 111 (1): 1-10.

De Oliveira, R.L.C., Lins Neto, E.M.F., Araújo, E.L., AlbuquerqueEt, U.P., 2007. Conservation priorities and population structure of woody medicinal plants in an area of Caatinga vegetation (Pernambuco State, NE Brazil). Environmental Monitoring and Assessment, 132: 189206. https://doi.org/10.1007/s10661-006-9528-7

Dewan, M.L., Famouri, J., 1964. The soils of Iran. Rome, Italy: Food and Agriculture Organization of the United Nations. 319 p.

Dietz, R. W., Czech, B., 2005. Conservation deficits for the continental United States: an ecosystem gap analysis. Conservation Biology, 19: 1478-1487.

Djamali, M., Akhani, H., Khoshravesh, R., AndrieuPonel, V., Ponel, P., Brewer, S., 2011. Application of the Global Bioclimatic Classification to Iran: implications for understanding the modern vegetation and biogeography. Ecologia Mediterranea, 37: 91-114.

Dobson, A.P., Rodriguez, J.P., Roberts, W.M., Wilcove, D.S., 1997. Geographic distribution of endangered species in the United States. Science, 275: 550-553.

Dolédec, S., Chessel, D., Gimaret-Carpentier, C., 2000 Niche separation in community analysis: a new method. Ecology, 81 (10): 2914-2927.

https://doi.org/10.1890/0012-9658(2000)081[2914:NSIC AA]2.0.CO;2

Dothan, F.N., 1986. Flora Palaestina. Vol. 4 (Iridaceae). Jerusalem: Academy of Science and Humanities, p. 112138.

EsRI, 2000. ArcView Gis Ver. 3.2a. California: Environmental Systems Research Institute Inc.

FedChenko, B.A., 1935. Flora of the USSR. Vol. 4 (Iridaceae). Leningrad: Academy of Science of USSR, p. 501-588. (In Russian).

Fernández, J. A ., Santana, O., Guardiola., J.L., Molina R.V., Harrison, P.H., Borbely, G., Branca, F., Argento, S., Maloupa, E., Talou, T., Thiercelin, J.-M., Gasimov, K., Vurdu, H., Roldán, M., Santaell, M., SAnchís, E. García-L., A., Suranyi, G., Molnár, A., Sramko, G., Gulyas, G., Balazs, L., Horvat, O., Rodríquez, M.-F., SÁnchez-Vioque, R., Escolano, M.-Á., Reina, J.-V., Krigas, N., Pastor, T., Renau-Morata, B., Raynaud, C., Ibadli, O., Polissiou, M., Tsimidou, M.Z., Tsaftaris, A., Sharaf-Eldin, M., Medina, J., Constantinidis, T.,
Caramplianis, T., De-Los-Mozos-Pascual, M., 2011. The world saffron and Crocus collection: strategies for stablishment, management, characterization and utilization. Genetic Resources and Crop Evolution, 58: 125-137. https://doi.org/10.1007/s10722-010-9601-5

Frey, W., Probst, W., 1986. A synopsis of the vegetation of Iran. In KüRSCHNER, H. (ed). Contributions to the vegetation of southwest Asia. Wiesbaden: Ludwig Reichert, p. 61-73.

Grilli Caiola, M.G., CaPUto, P., Zanier, R., 2004. RAPD analysis in Crocus sativus L. accessions and related Crocus species. Biologia Plantarum, 48: 375-380. https:// doi.org/10.1023/B:BIOP.0000041089.92559.84

Hammer, Q., Harper, D.A., RYAn, P.D., 2001. PAST Software. Palaeontological Association.

Harpke, D., Meng, S., Rutten, T., Kerndorff, H., BlattNeR, F.R., 2003. Phylogeny of Crocus (Iridaceae) based on one chloroplast and two nuclear loci: ancient hybridization and chromosome number evolution. Molecular Phylogenetics and Evolution, 66: 617-627. https://doi.org/10.1016/j.ympev.2012.10.007

Harpke, D., Peruzzi, L., Kerndorff, H., Karamplianis, T., Constantinidis, T., RanĐelović, V., RanĐelović, N., JušKović, M., PAsche, E., Blattner, F.B., 2014. Phylogeny, geographic distribution and new taxonomic circumscription of the Crocus reticulatus species group (Iridaceae). Turkish Journal of Botany, 38: 1182-1198.

Hedge, I.C., Wendelbo, P., 1978. Patterns of distribution and endemism in Iran. Notes from the Royal Botanic Garden, 36: 441-464.

Heywood, V.H., Dulloo, M.E., 2005. In situ conservation of wild plant species: a critical global review of best practices. IPGRI Technical Bulletin, No. 11. Rome, Italy: IPGRI. $174 \mathrm{p}$.

Homke, S., Verges J., Emami, H., Garces, M.R., 2004. Magnetostratigraphy of Miocene-Pliocene Zagros foreland deposits in the front of the Push-e Kush Arc (Lurestan Province, Iran). Earth and Planetary Science Letters, 225 (3-4): 397-410.

Iriondo, J.M., MAXTEND, N., Dulloo, M.E., 2008. Conserving plant genetic diversity in protected areas. Wallingford: CAB International Publication. $288 \mathrm{p}$.

IUCN, 2011. Guidelines for appropriate uses of IUCN Red List Data. Incorporating the Guidelines for Reporting on Proportion Threatened and the Guidelines on Scientific Collecting of Threatened Species. Version 9. Switzerland: Adopted by the IUCN Red List Committee and IUCN SSC Steering Committee. $78 \mathrm{p}$.

JAFARBEyglu, M., Mobaraky, Z., 2008. The land proportion evaluation in Qazvin province for Saffron cultivation based on multi-criteria decision making method. Journal of Natural Geographic Research, 66: 101-119. (In Persian with English summary).

JAFARI, M., 2010. Climate change impacts on Iranian ecosystems. Iran: Research Institute of Forests and rangelans. $332 \mathrm{p}$.

Johnson, C.N., 1998. Species extinction and the relationship between distribution and abundance. Nature, 394: 27274. https://doi.org/10.1038/28385 
KANDEMIR, N., 2009. A morphological, anatomical and ecological investigation on endemic Crocus pestalozzae Boiss. (Iridaceae) critically endangered in North-West of Turkey. Bangladesh Journal of Botany, 38: 127-132.

Kandemir, N., Çelik, A., Yayla, F., 2012. Comparative anatomic and ecologic investigations on some endemic Crocus taxa (Iridaceae) in Turkey. Pakistan Journal of Botany, 44 (3): 1065-1074.

Kapos, V., Rhind, J., Edwards, M., Price, M.F., Ravilious, C., 2000. Developing a map of the world's mountain forests. In Price, M.F., ButT, N. (eds). Forests in sustainable mountain development: a state-of-knowledge report for 2000. Wallingford: CAB International, p. 4-9.

KerndorfF, H., PASCHE, E., 2006. Crocus biflorus in Anatolia, part three. Linzer Biologische Beiträge, 38: 165-187.

KhattaK, I.M., Khattak. M.I., 2011. Study of heavy trace metals in some medicinal-herbal plants of Pakistan. Pakistan Journal of Botany, 43: 2003-2009.

Khoury, C., Laliberte', B., Guariano, L., 2010. Trends in ex situ conservation of plant genetic resources: a review of global crop and regional conservation strategies. Genetic Resources and Crop Evolution, 57: 625-639. https://doi. org/10.1007/s10722-010-9534-z

Kier, G., Mutke, J., Dinerstein, E., Ricketts, T.H., Küper, W., Kreft, H., Barthlott, W., 2005. Global patterns of plant diversity and floristic knowledge. Journal of Biogeography, 32 (7): 1107-1116. https://doi. org/10.1111/j.1365-2699.2005.01272.x

Kraefte, H., JetZ, W., 2007. Global patterns and determinants of vascular plant diversity. Proceedings of National Academy of Sciences, 104 (14): 5925-5930. https://doi. org/10.1073/pnas.0608361104

Larsen, B., 2011. Origin of Crocus sativus (Iridaceae): inter- and intraspecific variation, population structure and hybridization compatibility within Series Crocus. Master Thesis in Horticultural Sciences. University of Copenhagen, Denmark.

Louca, M., Vojiatakis, I.N., Moustakas, A., 2015. Modelling the combined effects of land use and climatic changes: coupling bioclimatic modelling with Markov-chain cellular automata in a case study in Cyprus. Ecological Informatics, 30: 241-249. https://doi.org/10.1016/j. ecoinf.2015.05.008

Lundmark, M., Hurry, V., Lapointe, L., 2009. Low temperature maximizes growth of Crocus vernus (L.) Hill via changes in carbon partitioning and corm development. Journal of Experimental Botany, 60 (7): 2203-2213. https://doi.org/10.1093/jxb/erp103

Lyberis, N., Manby, G., 1999. Oblique to orthogonal convergence across the Turan Block in the post-Miocene. AAPG Bulletin, 83 (7): 1135-1160.

Margules, C.R., Pressey, R.L., 2000. Systematic conservation planning. Nature, 405: 243-253.

Mathew, B., 1982. The Crocus. Portland: Timber Press. 127 p.

Mathew, B., 1984. Crocus. In Davis, P.H. (ed.). Flora of Turkey and the East Aegean Islands. Vol. 8. Edinburgh: Edinburgh University Press, p. 413-438.

Matthies, D., Brauer, I., Maibom, W., Tscharntke, T., 2004. Population size and the risk of local extinction: empirical evidence from rare plants. Oikos, 105: 481-
488. https://doi.org/10.1111/j.0030-1299.2004.12800.x

Maxted, N., Ford-Lloyd, B.V., Jury, S., Kell, S., Scholten, M., 2006. Towards a definition of a crop wild relative. Biodiversity \& Conservation, 15 (8): 2673-2685. https://doi.org/10.1007/s10531-005-5409-6

Mehrabian, A.R., 2014. Principles of plant conservation: challenges and methods. Tehran: Shahid Beheshti University. 323 p. (In Persian).

Mehrabian, A.R., Amini Rad, M., Pahlevani, A.H., 2015. The map of distribution patterns of Iranian endemic monocotyledons. Shahid Beheshti University, Tehran.

Mehrabian, A.R., Sayadi, S., 2018. The map of distribution patterns and conservation status of Iranian crop wild relatives (GP1). Shahid Beheshti University, Tehran.

Mehrabian, A.R., Sayadi, S., Kuhbanani, M. M., Hashemi V., Abdoljabari, M., 2020. Priorities for conservation of endemic trees and shrubs of Iran: Important Plant Areas (IPAs) and Alliance for Zero Extinction (AZE) in SW Asia. Journal of Asia-Pacific Biodiversity, 13: 295-305. https://doi.org/10.1016/j.japb.2019.09.010

Mehrabian, A.R., Khajoei Nasab, F., Amini Rad, M., 2021. Distribution patterns and priorities for conservation of Iranian Endemic Monocots: determining the Areas of Endemism (AOEs). Journal of Wildlife and Biodiversity, 5 (2): 69-87. https://10.22120/jwb.2020.136616.1188

Mutke, J., Barthlott, W., 2005. Patterns of vascular plant diversity at continental to global scales. In FriIs, I., Balslev, H. (eds). Plant diversity and complexity patterns: local, regional and global dimensions. Biologiske Skrifter, 55. Copenhagen: The Royal Danish Academy of Sciences and Letters, p. 521-537.

Myers, N., 1988. Threatened biotas: "hot spots" in tropical forests. Environmentalist, 8: 187-208. https://doi. org/10.1007/BF02240252

Myers, N., 1990. The biodiversity challenge: expanded hotspots analysis. Environmentalist, 10: 243-256. https:// doi.org/10.1007/BF02239720

Myers, N., Mittermeier, R.A., Mittermeier, C.G., DA FonseCA, G.A.B., 2000. Biodiversity hotspots for conservation priorities, Nature, 403: 853-858. https://doi. org/10.1038/35002501

Neghil, M., 1999. Saffron: Crocus sativus L. Amsterdam: Harwood Academic. $154 \mathrm{p}$.

Parenti, L.R., EвaCH, M.C., 2009. Comparative biogeography. California: University of California Press. $295 \mathrm{p}$.

Peruzzi, L., Carta, A., 2011. Crocus ilvensis sp. nov. (sect. Crocus, Iridaceae), endemic to Elba Island (Tuscan Archipelago, Italy). Nordic Journal of Botany, 29: 6-13.

Petersen, G., Seberg, O., Thorsoe, S., Jorgensen, T., Mathew, B., 2008. A phylogeny of the genus Crocus (Iridaceae) based on sequence data from five plastid regions. Taxon, 57 (2): 487-499.

Petit, J., El Mousadik, A., Pons, O., 1998. Identification of populations for conservation on the basis of genetic markers. Conservation Biology, 12: 844-855.

PoczAI, P.K., 2011. Molecular genetic studies on complex evolutionary processes in archaesolanum (Solanum, Solanaceae). $\mathrm{PhD}$ thesis. University of Pannonia, Keszthely, Hungary. 
Post, G.E., 1933. Flora of Syria, Palestina and Sinai. Vol. 11 (Iridaceae: Crocus L.). Beirut: American Press, p. 583586.

Prendergast, J.R., Quinn, R.M., Lawton, J.H., 1999. The gaps between theory and practice in selecting nature reserves. Conservation Biology, 13: 484-492.

Prendergast, J.R., Quinn, R.M., Lawton, J.H., Eversham, B.C., Gibbons, D.W., 1993. Rare species, the coincidence of diversity hotspots and conservation strategies. Nature, 365: 335-337. https://doi.org/10.1038/365335a 0

Reshinger, K.H. (ed.), 1975. Flora Iranica. Vol. 112. Graz, Austria: Akademische Druck- und Verlagsanstalt, p. 2-11.

SATIL, F., SELVI, S., 2007. An anatomical and ecological study of some Crocus L. taxa (Iridaceae) from the West part of Turkey. Acta Botanica Croatica, 66: 25-33.

SAYAdI, S., Mehrabian, A.R., 2016. Diversity and distribution patterns of Solanaceae in Iran: implications for conservation and habitat management with emphasis on endemism and diversity in SW Asia. Rostaniha, 17 (2): 136-160.

Scheiner, S.M., Rey-Benayas, J.M., 1994. Global patterns of plant biodiversity. Evolutionary Ecology, 8: 331-347. https://doi.org/10.1007/BF01238186

SchönBeCK-TemesY, E., 1972. Solanaceae. In Rechinger, K.H. (ed). Flora Iranica. Vol. 100. Graz, Austria: Akademische Druck- und Verlagsanstalt.

Shakur, A., Roshan, G., Kani, A.A.N., 2010. Evaluating climatic potential for palm cultivation in Iran with emphasis on degree-day index. African Journal of Agricultural Research, 5: 1616-1626.

Sheidai, M., Tabasi, M., Mehabian, A. R., Koohdar, F., Ghasemzadeh-Baraki, S., Noormohammadi, Z., 2018. Species delimitation and relationship in Crocus L. (Iridaceae). Acta Botanica Croatica, 77 (1): 10-17.

ŞIK, L., CANDAN, F., 2009. Ecological properties of some Crocus taxa in Turkey. African Journal of Biotechnology, 8 (9): 1895-1899.

STÖCKLIN, J., 1968. Structural history and tectonics of Iran: a review. AAPG Bulletin, 52 (7): 1229-1258.

StöcklIN, J., 1974. Northern Iran: Alborz Mountains. Geological Society Special Publications, 4 (1): 213-234.

Tabasi, M., Sheidai, M., Mehrabiam,A. R., NoOrmohammadi, Z., 2015. Population assessment of some Crocus species in Iran based on morphological and habitat characteristics. In Proceedings 2nd National conference on climate change and engineering sustainable agriculture and natural resourses. Tehran: Shahid Beheshti University, p. 1-7.
Tä́chHolm, V., Drar, M., 1973. Flora of Egypt. Vol. 3, Angiosperma, part Monocotyledons: Liliaceae: Musaceae. Koenigstein - Ts./B.R.D.: Otto Koeltz Antiquariat.

TAKHTAJAN, A., 1986. Floristic regions of the world. California: University of California Press. 544 p.

Tammaro, F., 1987. Notizie storico-colturalisullo zafferano (Crocus sativus L., Iridaceae) nell'area mediterranea [Saffron (Crocus sativus L., Iridaceae) in the Mediterranean area - historical and cultural aspects]. Micologia e Vegetazione Mediterranea, 2: 44-59.

Tsiftsis, S., Tsiripidis, I., Karagainnakidou, V., 2009. Identifying areas of high importance for orchid conservation in East Macedonia (NE Greece). Biodiversity \& Conservation, 18: 1765-1780.

VAVILOV, N.I., 1926. Studies on the origin of cultivated plants. Bulletin of Applied Botany and Plant Breeding, 14: $1-245$.

VAVILOv, N.I., 1951. The origin, variation, immunity and breeding of cultivated plants. Chronica Botanica, 13: 1-366. (Translated from Russian by K.S. Chester).

Wendelbo, P., 1985. Flora of Iraq. Vol. 8. (Iridaceae). Baghdad: Ministry of Agriculture, p. 226-257.

Williams, P., Gibbons, D., Margules, C., Rebelo, A., Humphries, C., Pressey, R.L., 1996. A comparison of richness hotspots, rarity hotspots and complementary areas for conserving diversity using British birds. Conservation Biology, 10: 155-174. https://doi.org/10.1046/j.15231739.1996.10010155.x

Yue, J., Wang, R., Ma, X., Liu, J., Lu, X., Balaso Thakar, S., An, N., LiU, J., Xia, E., LiU, Y., 2020. Full-length transcriptome sequencing provides insights into the evolution of apocarotenoid biosynthesis in Crocus sativus. Computational and Structural Biotechnology Journal, 18: 774-783.

ZAhran, M.A., 2010. Climate-Vegetation: Afro-Asian Mediterranean and Red sea coastal lands. New York: Springer Science \& Business Media. 324p.

Zohary, M., 1973. Geobotanical foundations of the Middle East. Vol. 1-2. Stuttgart: Gustav Fischer Verlag Press. 739 p.

Zubor, Á.A., SurÁnyi, G., Gyóri, Z., Borbély, G., Prokisch, J., 2004. Molecular biological approach of the systematics of Crocus sativus L. and its allies. Acta Horticulturae, 650: 85-93.

Submitted December 22, 2020 Accepted June 7, 2021 